\begin{tabular}{|c|c|}
\hline ב & $\begin{array}{c}\text { International Journal of Current Research } \\
\text { and Academic Review }\end{array}$ \\
\hline $\begin{array}{l}\text { XCELLENT } \\
\text { UBLISERERS }\end{array}$ & $\begin{array}{c}\text { ISSN: 2347-3215 (Online) }:, ; \text { Volume } 5:, ; \text { Number } 11 \text { (November-2017) } \\
\text { Journal homepage: http://www.ijcrar.com }\end{array}$ \\
\hline
\end{tabular}

doi: https://doi.org/10.20546/ijcrar.2017.510.010

\title{
Total Phenolic Content in the petals and Oral Acute Toxicity of gossypitrin on Wistar Rats
}

\author{
José Gonzalez ${ }^{1 *}$, Armando Cuéllar ${ }^{1}$, Dayné Franco², Max Monan ${ }^{3}$, Enmanuel Nossin ${ }^{3}$ and $^{2}$ \\ Frantz François-Haugrin ${ }^{3}$
}

${ }^{1}$ Department of Pharmacy, Faculty of Pharmacy and Foods, Havana University, Havana 10400, Cuba

${ }^{2}$ Centro de Investigaciones Apicolas, La Habana, Cuba

${ }^{3}$ ARVARNAM, Martinica 97220, France

*Corresponding author

\section{Abstract}

Talipariti elatum Sw. (Fryxell) Malvaceae is a quite attractive tree with its straight trunk, broad green leaves, and hibiscus-like flowers. This medicinal plant is use in various traditional medicine therapeutic applications in Cuba, especially in treatment of bronchial asthma and flu. From ethanolic and toluene extracts of the flowers our research group have characterized more than 50 different chemical compounds as secondary metabolites. One of them, gossypitrin, a glucoside flavonoid isolated and purified from ethanolic extract of the petals had been reported as antibacterial and antifungal and to possess a remarkable antioxidant activity against a lot of amount of different ROS and RNS. Here, in our study, we realized the determination of total phenolic content from the total ethanolic extract using the petals of the flowers and the measurements of the oral acute toxicity of the main flavonoid in the petals of the flowers of T. elatum.
\end{abstract}

\section{Article Info}

Accepted: 28 October 2017

Available Online: 20 November 2017

\section{Keywords}

Talipariti,

Petals,

Phenolic content,

Oral acute toxicity,

Gossypitrin.

\section{Introduction}

Medicinal plants utilized as alternative therapy are generalizing again as faster as possible not only in underdevelopment countries, but, in development countries too, not only for their efficacy, due to their security and their indocility during the treatments and Cuba is not an exception.

Talipariti elatum is native to the islands of Cuba, Jamaica, US, Virgin Islands, Puerto Rico and Martinica. In wetter areas it will grow in a wide range of elevations, up to 1200 meters (3900 Ft.) and is often used in reforestation. It is the national tree of Jamaica. Talipariti elatum tree is quite attractive with its straight trunk, broad green leaves and hibiscus-like flowers. The attractive flower changes color as it matures, going from bright yellow to orange, red and finally to crimson (Figure 1). It grows quite rapidly, often attaining 20 meters (66 Ft.) or more in height. The name mahoe is derived from a Caribe word. The "blue" refers to bluegreen streaks in the polished wood, giving it a distinctive appearance (1).

From the petals of their flowers our research team have isolated and characterized 30 different chemical compounds by UV, IR, UHPLC-MS/MS and NMR. The main chemical components in the ethanolic extracts of 
this part are flavonoid and their derivate such as gossypitrin, gossypetin-3'-O-glucoside, quercetin-3-Oglucoside and isomer, kaempferol, protocatechuic acid and quercetin- $O$-sambubioside, etc. (2) (3) (4).

The aim of the present work was to determine the total phenol content in an ethanolic extract from the petals of the flowers of Talipariti elatum S.w and to evaluate the oral acute toxicity of the main chemical compound in this flower part in order to rationalize an envisaged production of phytomedicines.

\section{Materials and Methods}

\section{Plant Material}

Flowers were collected in January 2016 in the gardens of the Faculty of Pharmacy and Foods at Havana University, and identified at the herbarium of National Botany Garden of Havana, where the voucher specimen no. HAJB 82587 has been deposited. The flowers were collected after their mature and separated into their constituent parts: petals, chalices and pistils with pollen.

\section{Chemicals}

All chemicals were purchase from Merck (Darmstadt, Germany). Analytical ethanol, Folin-Ciocalteu reagent, gallic acid, sodium carbonate and distilled water were used in the analysis work. All solvents were degassing previously before used in an ultrasonic bath without filtration.

\section{Extract and Samples Preparation}

Dark red flowering types were collected daily. The isolated petals used were dried in an oven with controlled temperature, at $40^{\circ} \mathrm{C}$, during 5 days. The extracts were prepared with the ground material $(60 \mathrm{~g})$ without screen extracted in a Soxhlet apparatus with $675 \mathrm{~mL}$ of ethanol at $95 \%$ during 20 hours. The ethanolic extracts were concentrated and evaporated under vacuum to $200 \mathrm{~mL}$ at $120 \mathrm{rpm}$, a temperature of $70^{\circ} \mathrm{C}$ and $500 \mathrm{mbar}$.

For to the purification, $1 \mathrm{~g}$ of solid was dissolved in 25 $\mathrm{mL}$ of diethyl ether and the volume was completed to $100 \mathrm{~mL}$ with ethanol. The sample was refrigerated until an abundant solid appear and it was recuperated to filtration. This process was done twice, to obtain only a yellowish-green solid monitoring by TLC on silica gel with fluorescent indicator $254 \mathrm{~nm}$ on aluminum cards (layer thickness $0.2 \mathrm{~mm})(10 \times 20 \mathrm{~cm})$ using n-butanol: acetic acid: water (4:1:5) as eluent (v/v/v) (2).

\section{Total phenols}

Total phenols were measured in triplicate from an ethanolic dry extract of the petals, according to the method of NOA, 2008 (5), using the Folin-Ciocalteu reagent and gallic acid as standard. Absorbances were read at $765 \mathrm{~nm}$ on spectrophotometer Jenway 6705 UV/Vis (UK). Results are expressed as gallic acid equivalents (GAE)/g of dried extract.

\section{Oral Acute Toxicity}

The acute toxicity test was measured according to the method of Commission of the European Communities $\mathrm{N}^{\circ}$ 423, 1996 (6). Six young adult rats (3 males and 3 females) of Wistar line from Center of Production of Laboratory Animals (CENPALAB) in Bejucal, Mayabeque Province, Cuba. For this assay two groups of animals (3 per gender) were treated with gossypitrin using a gastric cannula with a single dosage at 2000 $\mathrm{mg} / \mathrm{Kg}$ of weight ( $2 \mathrm{~mL} / 200 \mathrm{~g}$ of weight constantly).

After 2-3 hours of finished the administration of the substance the animals were feed again. All animals were observed and the behavior registered in individual records several times during the first day and at least once a day during 13 days more to complete the procedure. At the end of the test the animals were sacrificed using diethyl eter. The organs (lungs, hearts, kidneys, stomachs, etc.) were extracted and observed if they are affected. If some of the organs were affected were taken samples for the histopathology analyses. The weight of the animals was processed statistically to register the mean and standard deviation.

\section{Results and Discussion}

\section{Determination of total polyphenols}

For this assay an ethanolic dry extract from the petals of the flowers of Talipariti elatum Sw. was achieved, and three sets of measures performed. Three determinations with gallic acid as standard were carried out in five points. Absorbances were measured at $765 \mathrm{~nm}$. The curve of the average absorbance versus concentrations (Fig. 2) is a straight line, which equation is: $\mathrm{A}=\mathrm{mC}+\mathrm{n}$ were $m$ is the pendent; $C$ is the concentration and $n$ is the intercept (Table 1). 
Calculation of total polyphenols in Gallic Acid Equivalent (GAE) of the dry extract of Talipariti elatum Sw. from the petals of the flowers was made taking into account the three determinations with gallic acid, and the ethanolic dry extract assay.

The rate of total polyphenols in the extract of Talipariti elatum Sw. equal to $168 \pm 1 \mathrm{mg} \mathrm{GAE} / \mathrm{g}$ of dry extract. Comparing this value with those obtained with the same method by Wong et al., (2010) (7) for other species of Hibiscus, we can see in Table 2 that total polyphenols of our sample is higher. Our result is close to that of
Martinica where François-Haugrin et al., 2016 (8) found that in the same plant, but using the whole flowers with a value of $163 \pm 1 \mathrm{mg} \mathrm{GAE} / \mathrm{g}$ of dry extract.

\section{Determination of Oral Acute Toxicity of Gossypitrin}

The results of the test to determine the oral acute toxicity of gossypitrin demonstrated that the glucoside flavonoid classified as non-toxic according to the classification system of the Commission of the European Communities. The flavonoid belongs to class $\mathrm{CTA}_{0}$ in which the Mortality > 2000.

Fig.1 Talipariti elatum Sw. (Tree, flower and leaf)

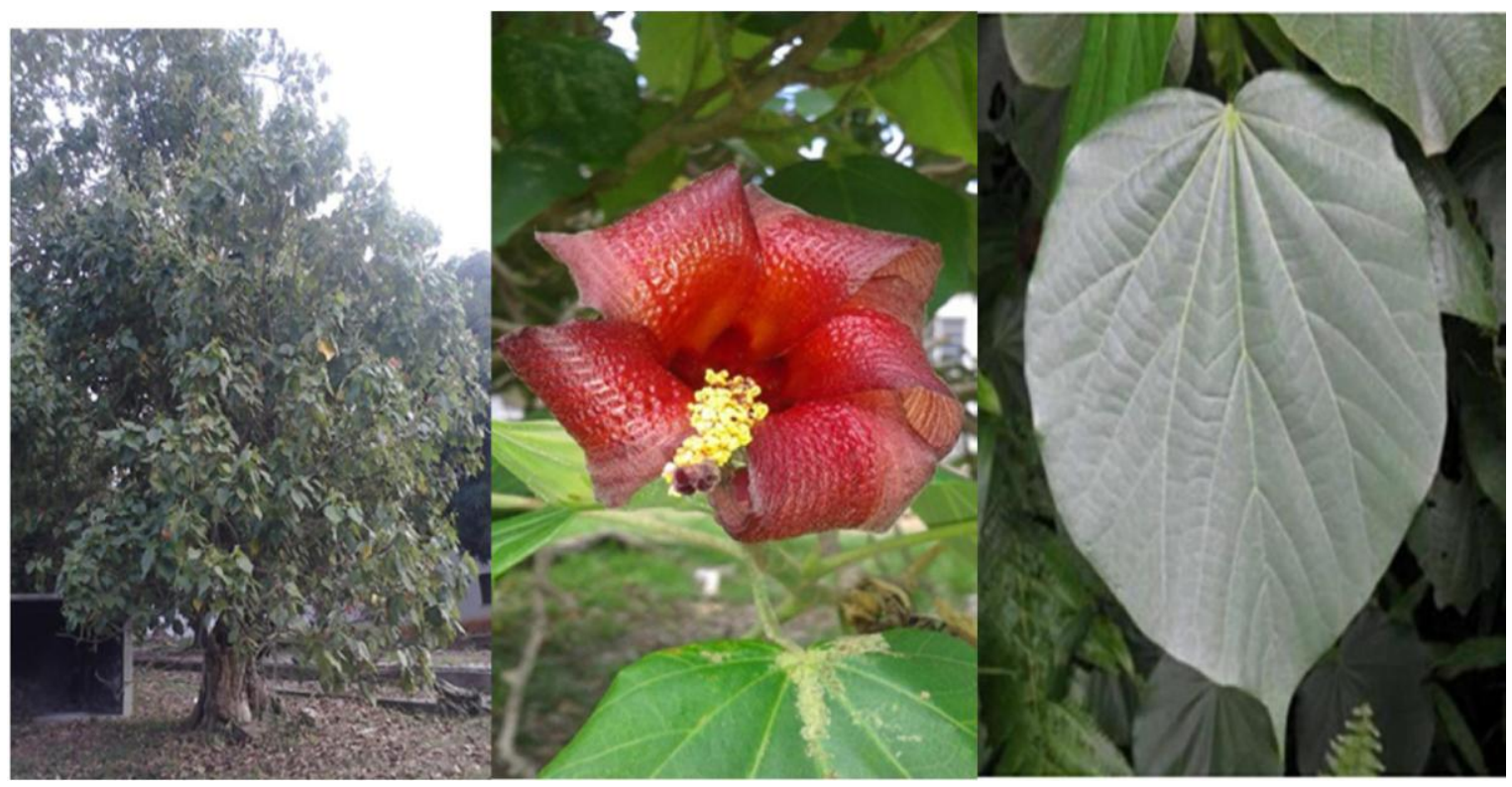

Fig.2 Curve of determination of total polyphenols of the ethanolic dry extract of Talipariti elatum $\mathrm{Sw}$

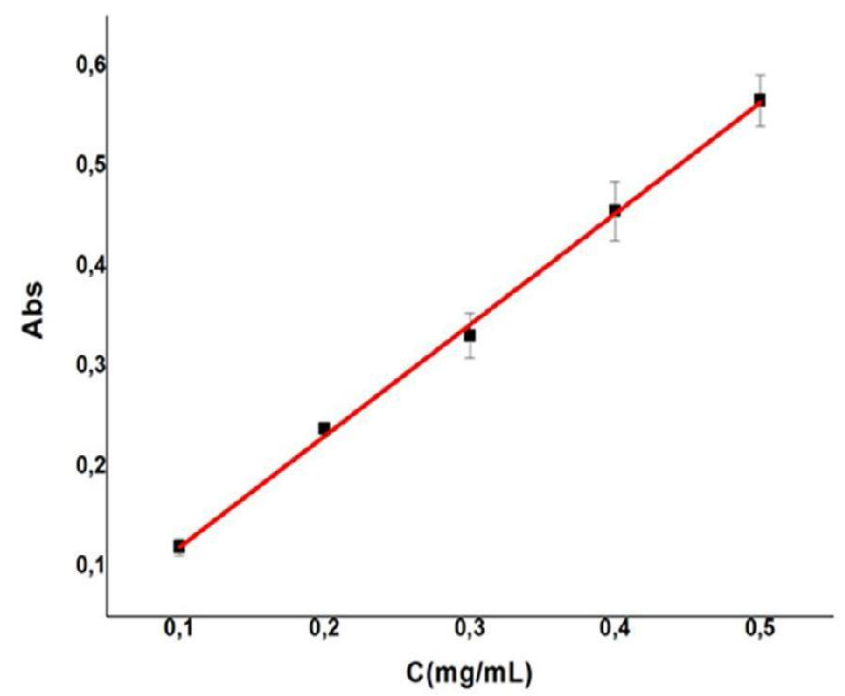


Fig.3 Variation of weight during the assay

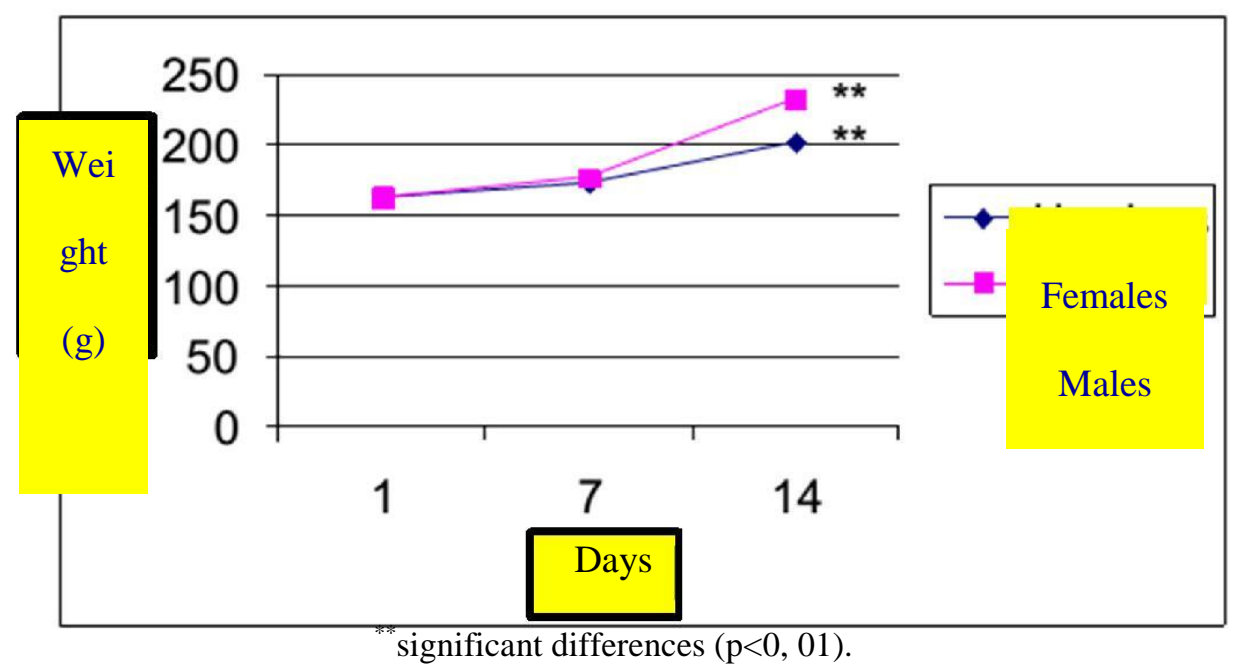

Table.1 Parameters of total polyphenols determination

\begin{tabular}{|c|cc|c|}
\hline Lineal Equation & \multicolumn{2}{|c|}{$\mathrm{A}=\mathrm{mC}+\mathrm{n}$} & \multicolumn{2}{c|}{ R-Square: 0.99814} \\
\hline Pendent $(\mathrm{m})$ & 1.11 & \pm 0.02 & $\begin{array}{c}\text { Concentration of ethanolic extract } \\
(\mathrm{mg} / \mathrm{mL})\end{array}$ \\
\hline Intercept $(\mathrm{n})$ & 0.008 & \pm 0.008 & $8.4 \pm 0.1$ \\
\hline
\end{tabular}

Table.2 Total polyphenols concentration of flowers of Hibiscus according to Wong et al., (2010) in GAE

\begin{tabular}{|c|c|}
\hline Hibiscus species & Total Polyphenols (mg GAE/g) \\
\hline H. tiliaceus & $24,20 \pm 1,67$ \\
\hline H. rosa-sinensis & $7,35 \pm 0,46$ \\
\hline H. taiwanensis & $5,80 \pm 0,79$ \\
\hline H. shizopetalus & $5,16 \pm 0,3$ \\
\hline H. mutabilis & $4,95 \pm 0,23$ \\
\hline
\end{tabular}

Oral administration of gossypitrin no lethality was produced at the employed dosage $(2000 \mathrm{mg} / \mathrm{Kg})$ in the used animals. During the 14 days of the experiment the animals do not manifested toxically signs on their skins, eyes, mucosal membranes and none system taken into account. Not evidence of convulsion, diarrhea, salivation, lethargy, sleep and coma were observed. At macroscopic level non pathologic changes were observed after realize the autopsy of the animals.

Moreover, the animal non experimented retard in the growth and the increase of corporal weights was normal during all the time of assay. Significant differences $(p<0$, 1) were found (for both sex) in the weight between the first and the last day of the experiment and between the 7 and 14. All these results permit that the flavonoid classified as non-toxic. None significant differences ( $p>0,01)$ were found between the increase of weight of the animals under assay according to the typical behavior inside the spice, sex and age (9) (10). Figure 3 show the variation of weight during the assay (1, 7 and 14 days).

For the first time determination of total polyphenols from an ethanolic extract of the petals of the flowers of $T$. elatum Sw. was developed. The rate $168 \pm 1 \mathrm{mg}$ EAG/g of dry extract is notably higher than those obtained with other species of Hibiscus (tiliaceus, rosa-sinensis, taiwanensis, schizopetalus, mutabilis), and closed to this 
spice cultivated in Martinica $(163 \pm 5 \mathrm{mg} \mathrm{GAE} / \mathrm{g}$ of dry extract). OAT (oral acute toxicity) of gossypitrin extracted and characterized from ethanolic extract of the petals demonstrated that the glucoside flavonoid tested is non-toxic at the unique dosage of $2000 \mathrm{mg} / \mathrm{Kg}$ of weight. The animals used in the assay no showed any kind of unusual symptoms in their behaviors and it was not necessary to do the histologic analysis because the observed organs were in good conditions.

\section{Acknowledgements}

The authors wish to thanks to MSc Gastón García Simón for his important contribution to develop the results in the OAT assays.

\section{References}

1. Commission of the european communities. 1996. J Eur Comm. (L 383 A) 35:110-112.

2. Cuéllar A, González J. 2010. Isolation of the glucoflavonoid Gossypitrin from the flowers of Talipariti elatum s.w. and the evaluation of its antioxidant activity. Rev. Colombiana Cienc. Anim. 2(2). 338-348.

3. Frantz François-Haugrin, Max Monan, Emmanuel Nossin, Juliette Smith-Ravin and Odile Marcelin. 2016. Antioxidant activity of an isomer of gossypitrin (gossypetin-3'-O-glucoside) isolated in the petals of Talipariti elatum Sw., and determination of total phenolic content of the total flower. Journal of Pharmacognosy and Phytochemistry 5(5): 200-208.

\section{How to cite this article:}

José Gonzalez, Armando Cuéllar, Dayné Franco, Max Monan, Enmanuel Nossin and Frantz François-Haugrin. 2017. Total Phenolic Content in the petals and Oral Acute Toxicity of gossypitrin on Wistar Rats. Int.J.Curr.Res.Aca.Rev. 5(11), 53-57. doi: https://doi.org/10.20546/ijcrar.2017.511.010
4. García G. 2011. Pre-clínica realizada con la materia prima activa. Laboratorios liorad. Informe final código: 11/64. Estudio de Toxicidad Aguda por la vía Oral de la GOSSYPITRINA procedente del IFAL.

5. José González, Armando Cuéllar, Loïk Sylvius, Frédéric Verdeau, Frantz François-Haugrin, Juliette Smith-Ravin and Odile Marcelin. 2017. New Phytochemical Profile of Ethanolic Extract from Talipariti elatum (Sw.). Journal of Pharmacy and Pharmacology 5 489-496.

6. NOA (Argentinean northwest) products Propolis Part 1 - Propolis in natura. 2008. IRAM-INTA 15935-1. 12-14.

7. U.S. Department of Agriculture (2013). Hibiscus elatus Sw. "mahoe". Natural Resources Conservation Service. Plants Database.

8. Wong SK, Lim YY, Cham EWC. 2010. Evaluation of Antioxidant, Anti-tyrosinase and Antibacterial Activities of Selected Hibiscus Species. Ethnobotanical Leaflets. 14:781-796.

9. Yaque, J. G., Cuéllar, A., Gaysinski, M., Monan, M., Nossin, E., and François-Haugrin, F. 2016. "New Reported Flavonol Characterized by NMR from the Petals of Talipariti elatum S.w. in Cuba." American Journal of Plant Sciences 7: 1564-9.

10. Yaque, J. G., Cuéllar, A., Massi, L., Monan, M., Nossin, E., and François-Haugrin, F. 2016. "Isolation and Characterization of Flavonols by HPLC-UV-ESI-MS/MS from Talipariti elatum S.w." American Journal of Plant Sciences 7: 1198204. 